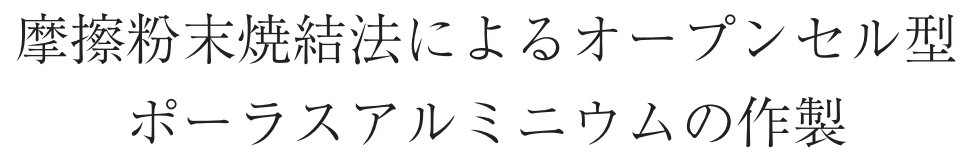

半谷 禎彦*·石原 綾乃**. 桑水流 理 $* * *$. 吉川 暢宏****

Journal of The Japan Institute of Light Metals, Vol. 64, No. 12 (2014), 628-632

(C) 2014 The Japan Institute of Light Metals

\title{
Fabrication of open-cell porous aluminum by friction powder sintering process
}

\author{
Yoshihiko HANGAI*, Ayano ISHIHARA**, Osamu KUWAZURU*** and Nobuhiro YOSHIKAWA****
}

\begin{abstract}
A new friction powder compaction process by the sintering and dissolution process route for fabricating open-cell porous aluminum $(\mathrm{Al})$, which requires no external heat sources except friction heat, was developed. The sintering of the mixture of $\mathrm{Al}$ and $\mathrm{NaCl}$ powders was conducted only by a rotating tool plunged into the mixture. Namely, the sintering of the mixture was achieved because of the friction heat and pressing load generated by the rotating tool plunged into the mixture. In this study, porous $\mathrm{Al}$ with porosities of $60 \%, 70 \%$ and $80 \%$ were successfully fabricated. Their pore structures were observed by SEM and X-ray computed tomography (CT), and their mechanical properties were investigated by compression tests. It was found that almost the entire specimen had pore structures similar to the $\mathrm{NaCl}$ morphology regardless of the porosity. Plateau stress decreased with increasing porosity indicating strong relationships between them. Porous Al exhibited ductile fracture regardless of its porosity, which is considered to be attributed to the good bonding between $\mathrm{Al}$ particles.
\end{abstract}

(Received April 20, 2014 Accepted July 31, 2014)

Keywords: cellular materials, sintering and dissolution process, friction welding, X-ray computed tomography, foam

\section{1. 緒言}

ポーラス金属は内部に多くの気孔が存在することから，軽 量であるとともに，衝撃吸収特性や吸音特性など多くの機能 を発現させることができる ${ }^{1 ｝ \text { 。特にオープンセル型（連通気 }$ 孔型）ポーラス金属は, 気孔と気孔がつながっているため, 気体や流体の流路とすることが可能である。比表面積が大き いため, ヒートシンクなどへの適用が期待されている ${ }^{2), 3) 。 ~}$

ポーラス金属を作製する方法には様々な手法が提案されて いる ${ }^{4)}$ 。 $。$ オープンセル型ポーラス金属の作製方法の一つ に焼結スペーサー法 (sintering and dissolution process, 以下 SDP）がある ${ }^{8) \sim 12)}$ 。SDPは，まず金属粉末とスペーサーと なる塩化ナトリウム $(\mathrm{NaCl})$ 粉末を混合・焼結する。焼結 体を水洗し, $\mathrm{NaCl}$ を溶解除去することで, 気孔を生成しポー ラス金属を作製するものである。混合した $\mathrm{NaCl}$ の形状が, ほぼそのまま気孔形状となる。また, 混合する金属粉末と $\mathrm{NaCl}$ 粉末の体積の割合が，ほぼそのまま作製するポーラス 金属の気孔率（試料全体に対する気孔の体積率）となる。そ のため，SDPは気孔形態を容易に制御できる。さらに, $\mathrm{NaCl}$
は安価で人体に無害であることや, 水への溶解度が高く常温 の水で容易に溶解除去できることなどから, 簡便で生産コス 卜を低く抑えられることが期待される。しかしながら, 混合 粉末の焼結には, 従来, 雲囲気全体を加熱する加熱炉が用い られ焼結に長い時間を要するため, さらなる生産性・省エネ ルギー性の向上が望まれている。

著者らは, 摩擦攪拌接合 ${ }^{13)}$ や摩擦圧接 ${ }^{14)}$ 等の摩擦発熱現 象を粉末の焼結に利用し, 䨌囲気全体の加熱が不要な摩擦粉

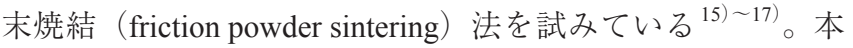
手法は，あらかじめ金属板にあけておいた穴に混合した金属 粉末と $\mathrm{NaCl}$ 粉末を投入し, その上から回転したツールを押 込み, その際に生じる摩擦熱および押込荷重により混合粉末 を焼結する。 $\mathrm{NaCl}$ の融点 $(1074 \mathrm{~K})$ は純アルミニウムの融 点 $(933 \mathrm{~K})$ よりも高いため, 焼結中に $\mathrm{NaCl}$ は溶融しない。 その後, $\mathrm{NaCl}$ を水中で除去してポーラス金属を得るもので ある。本手法は焼結で必要な個所に限定して摩擦熱を発生さ せるため, 省エネルギーな手法である。また, 通常の加熱炉 を用いるものなどと比較して, 短時間のプロセスで焼結でき るため，生産性および省エネルギー性に優れた手法であるこ

* 群馬大学大学院理工学府知能機械創製部門（†376-8515 群馬県桐生市天神町 1-5-1）。Division of Mechanical Science and Technology, Faculty of Science and Technology, Gunma University (1-5-1 Tenjin-cho, Kiryu-shi, Gunma 376-8515). E-mail: hanhan@gunma-u.ac.jp

** 群馬大学大学院理工学府理工学専攻知能機械創製理工学教育プログラム, 大学院生 (桐生市)。Division of Mechanical Science and Technology, Graduate School of Science and Technology, Gunma University (Kiryu-shi, Gunma).

***福井大学大学院工学研究科原子力・エネルギー安全工学専攻 (福井市)。Department of Nuclear Power \& Energy Safety Engineering, Graduate School of Engineering, University of Fukui (Fukui-shi, Fukui).

****東京大学生産技術研究所（目黒区)。Institute of Industrial Science, The University of Tokyo (Meguro-ku, Tokyo). 
(a)

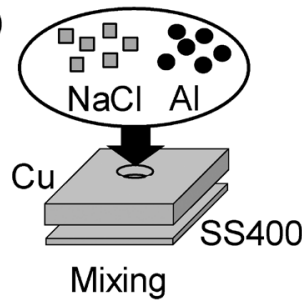

(b)

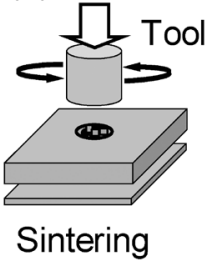

(c)

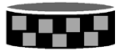

마무

Machining (d)

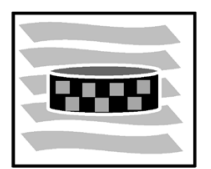

Leaching (e)

\section{$\overline{\mathrm{Bm}}$}

Porous Al

Fig. 1 Schematic illustration of friction powder sintering process based on sintering and dissolution process route for fabricating open-cell porous $\mathrm{Al}$.

とが期待される。過去の研究において，穴をあけた金属板と してアルミニウム板を用いてポーラスアルミニウムの作製を 試みたが，焼結が若干弱い傾向が見られた ${ }^{15)}$ 。そこで，ア ルミニウムよりも高融点で熱伝導性に優れた銅板を用いるこ とで, 気孔率 $74 \%$ のポーラスアルミニウムに扔いて, 強い 焼結が得られることがわかった ${ }^{16)}$ 。

本研究では, 摩擦粉末焼結法により銅板を用いて気孔率が $60 \%, 70 \%, 80 \%$ となるようなポーラスアルミニウム $(\mathrm{Al})$ の 作製を試み，それぞれの気孔率で強い焼結によるポーラス $\mathrm{Al}$ が作製可能か検討する。走查型電子顕微鏡（SEM）およ びX線CTによる観察から，本研究で作製したポーラス $\mathrm{Al}$ に おいても気孔形状が $\mathrm{NaCl}$ の形状を転写しているか検討する。 その上で，作製したポーラス $\mathrm{Al}$ の気孔率と圧縮特性との関 係について調査する。

\section{2. 実験方法}

\section{1 作製方法}

摩擦粉末焼結法の概略図を Fig. 1 に示す。まず, Al粉 末 (株式会社高純度化学研究所, 純度 $99.9 \%$, 粒径 $20 \mu \mathrm{m}$ 以 下）と $\mathrm{NaCl}$ 粉末（株式会社高純度化学研究所, 純度 $99.9 \%$, 粒径 $425 \sim 500 \mu \mathrm{m}$ に整粒）を気孔率 $p$ が $60 \%, 70 \%, 80 \%$ と なるように混合した。この混合粉末を Fig. 1(a)に示すよう に厚さ $t=10 \mathrm{~mm}$ の無酸素銅板にあらかじめあけておいた 穴 $(\phi=13 \mathrm{~mm})$ に投入した。この際, 無酸素銅板の下に厚さ $3 \mathrm{~mm}$ のSS400バックプレートを敷いた。次に, Fig. 1(b)に示 すように上から先端が平坦な超硬ツール（ $\phi=16 \mathrm{~mm}$ の中実 棒）を回転させながら押込み, 混合粉末を焼結した。この際, ツールの中心軸と無酸素銅にあけた穴の中心が一致するよう にした。ッールの回転数は $1000 \mathrm{rpm}$, 押込速度は $1 \mathrm{~mm} / \mathrm{min}$, 押込量はツール先端が無酸素銅板や粉末に接触した位置（高 さ）から $3 \mathrm{~mm}$ とした。ッールを $3 \mathrm{~mm}$ 押込んだ後, $10 \mathrm{~s}$ その ままの位置で保持し，その後ツールを上昇させた。ッール押 込中の温度は, 無酸素銅にあけた穴の外周から $5 \mathrm{~mm}$ のとこ ろを熱電対により測定した。この焼結したものから機械加工 により直径 $13 \mathrm{~mm}$, 厚さ $4.8 \mathrm{~mm}$ の円柱形状圧縮試験片を切出 した（Fig. 1(c)）。その後, Fig.1(d)に示すように圧縮試験片 を水中に静かに浸漬することで, $\mathrm{NaCl}$ を除去し，ポーラス $\mathrm{Al}$ を得た (Fig. 1(e))。 $\mathrm{NaCl}$ の除去は常温下で行った。その際, ある浸漬時間ごとに圧縮試験片を水中から取出し，433Kの 加熱炉中に $900 \mathrm{~s}$ 入れ乾燥させた上で重量測定を行い, $\mathrm{NaCl}$ 除去率を測定した。

\section{$2.2 \mathrm{X}$ 線CT撮像方法}

得られた圧縮試験片の気孔形態を観察するためのX $\mathrm{X}$ 線 CT 撮像は, 株式会社島津製作所のマイクロフォーカスX線 CT,

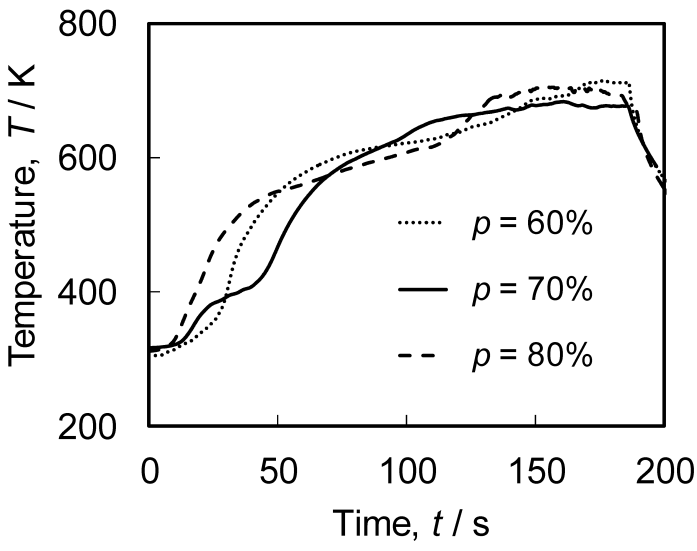

Fig. 2 Relationships between tool indentation time $t$ and temperature $T$ during friction powder sintering process for $p=60,70$ and $80 \%$.

SMX-225CTを用いて行った。X線源はタングステンであ り, 圧縮試験片全体をコーンビーム CT撮像した。撮像条件 は, X線管電圧 $80 \mathrm{kV}, \mathrm{X}$ 線管電流 $30 \mu \mathrm{A}$, 画像サイズ $512 \times 512$ pixelとした。このとき, 1 pixelの大きさは $40 \mu \mathrm{m}$ であった。

\section{3 圧縮試験方法}

得られたポーラス $\mathrm{Al}$ の圧縮特性はJIS-H-7902 ポーラス金 属の圧縮試験方法 ${ }^{18)}$ を参考にした静的圧縮試験により取得 した。圧縮試験は, 株式会社島津製作所の精密万能試験機 オートグラフ AG-100kNGを用いて, 圧縮速度（クロスヘッ ド速度） $1 \mathrm{~mm} / \mathrm{min} て ゙$ 行った。圧縮ひずみは, クロスヘッド 変位を初期の圧縮試験片高さで除することで求めた。同時に ビデオ撮影することで，変形挙動の外観観察も行った。それ ぞれの気孔率でそれぞれ4試行ずつ行った。

\section{3. 実 験 結果}

Fig. 2 に押込時間 $t$ と温度 $T$ の関係を示す。 $t$ はツール先 端が無酸素銅板および粉末に接触した時点を 0 としている。 ッールが接触し始めると押込量の増加とともに温度は急激に 上昇する。 $t=50 \sim 70$ sに执いて温度の上昇は徐々に緩やかに なる。これは押込量の増加により入熱量は増加するものの, 温度上昇に伴う放熱量も多くなるためと考えられる。その 後, ほぼ一定で推移し最高温度に到達する。押込みが終わり その場で $10 \mathrm{~s}$ 保持している間（ $t=180 \sim 190 \mathrm{~s} ）$ も温度はほぼ 一定である。 $t=190 \mathrm{~s}$ でツールが上昇すると温度は急激に下が る。この傾向は気孔率にかかわらずほほ同様であった。最高

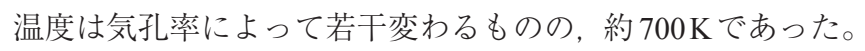
$\mathrm{NaCl}$ 粉末を混合せず $\mathrm{A} 1$ 粉末のみ焼結する予備実験において, 回転ツールが直接接触した面近傍と回転ツール接触部から一 


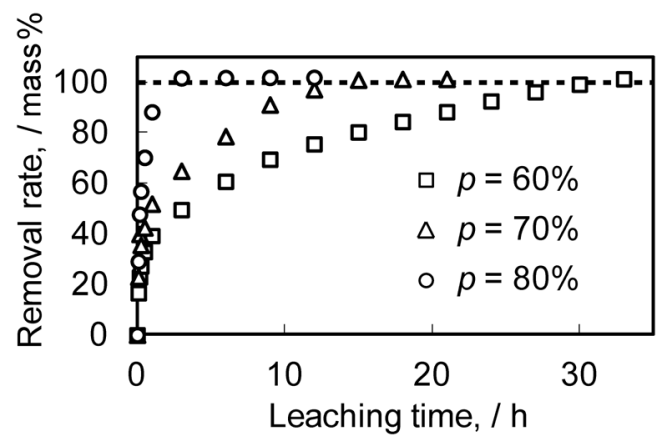

Fig. 3 Relationship between leaching time and $\mathrm{NaCl}$ removal rate for $p=60,70$ and $80 \%$.
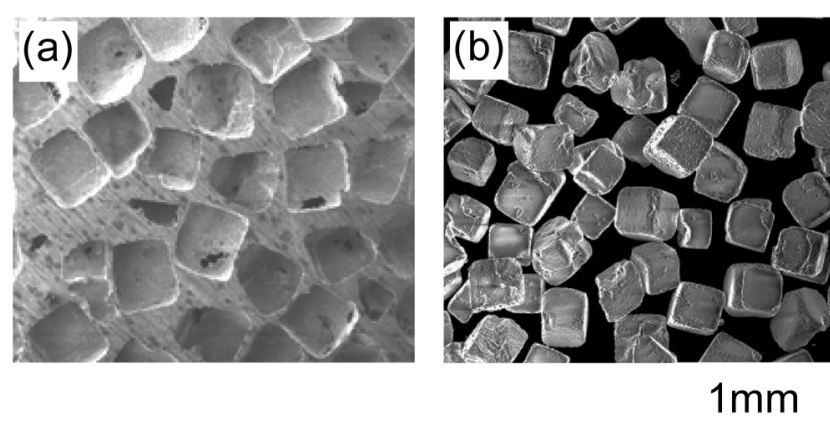

Fig. 4 SEM images of (a) pore structures of fabricated porous $\mathrm{Al}$ with $p=70 \%$ and (b) $\mathrm{NaCl}$ used as spacer.

番離れた部分の粉末の温度（熱電対を粉末に入れ計測）は,

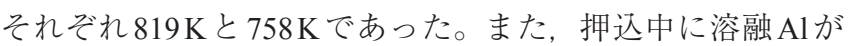
噴き出すことはなかった。これらのことから， $\mathrm{Al}$ 粉末はア ルミニウムの融点 $(933 \mathrm{~K})$ までは到達していないと考えら れる。

Fig. 3 に圧縮試験片の水中浸漬時間と $\mathrm{NaCl}$ 除去率の関係を 示す。 $0 \%$ が浸漬前の初期状態で $100 \%$ になると $\mathrm{NaCl}$ がすべて 除去されたことを示している。気孔率にかかわらず，浸漬開 始後, 急速に $\mathrm{NaCl}$ は除去され, 徐々に緩やかになっていく。 これは, 水に触れやすい試験片の外側から $\mathrm{NaCl}$ の除去が進 み, $\mathrm{NaCl}$ の除去が進行すると $\mathrm{NaCl}$ の存在個所が内部だけと なり，除去されにくくなるためである ${ }^{15)}$ 。本研究の試験片形 状であれば， $\mathrm{NaCl}$ は $p=80 \%$ において約 3 時間， $p=60 \%$ におい て約 30 時間ですべて除去されることがわかる。気孔率が高い ほど， $\mathrm{NaCl}$ の除去の進行が早い傾向にあり，これは，気孔が 多いと多くの水が内部まで浸入しやすいためと考えられる。

Fig. 4(a)に気孔率が70\%の圧縮試験片の裏表面における気 孔のSEM 画像を，Fig. 4(b)にスペーサーとして用いた $\mathrm{NaCl}$ のSEM画像を示す。気孔一つ一つはほぼ⿴囗十角い形状をして おり, $\mathrm{NaCl}$ の形状がそのまま気孔形状に反映されているの がわかる。気孔壁の一部に穴があいているのが観察されオー プンセル構造となっており，この部分から水が浸入し $\mathrm{NaCl}$ が溶解したものと考えられる。他の気孔率においても同様の 傾向であった。ただし，後述のようにツール接触面近傍では 気孔形状の変形も一部見られた。

Fig. 5 に気孔率 $60 \%, 70 \%, 80 \%$ の圧縮試験片における高さ 方向中部付近断面の X線 CT 画像を示す。白い部分が $\mathrm{Al}$ 母材 であり，内部の黒い部分が気孔である。気孔率の増加ととも

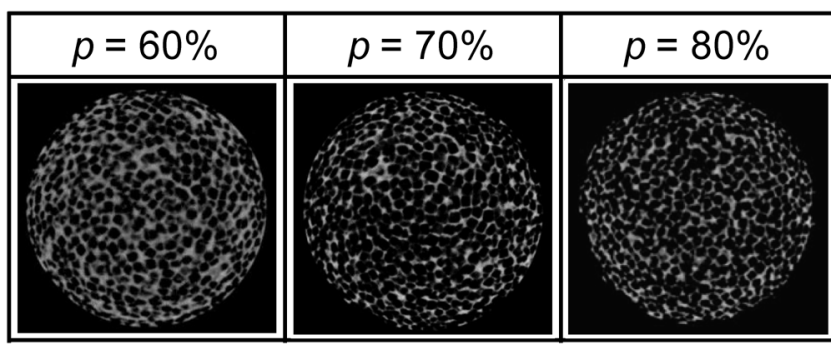

$5 \mathrm{~mm}$

Fig. 5 X-ray CT images of pore structures of fabricated porous $\mathrm{Al}$ with $p=60,70$ and $80 \%$ taken at middle position.

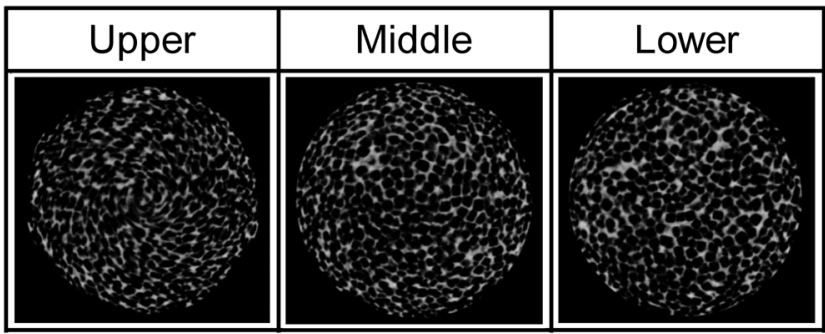

$5 \mathrm{~mm}$

Fig. 6 X-ray CT images of pore structures of fabricated porous $\mathrm{Al}$ with $p=70 \%$ taken at upper, middle and lower positions.

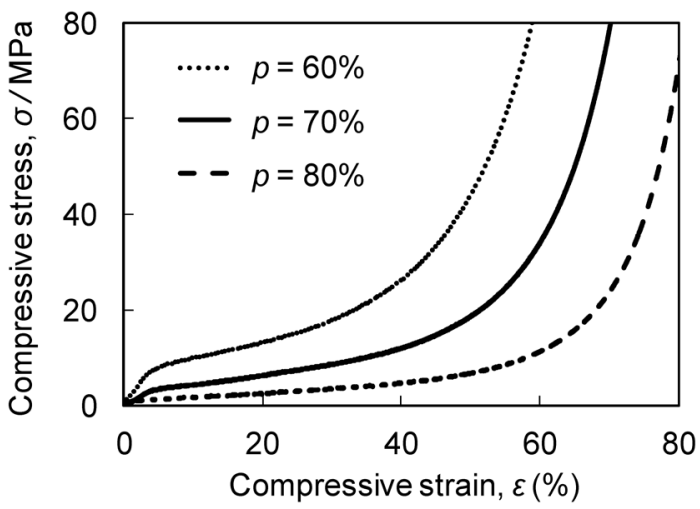

Fig. 7 Stress-strain curves for fabricated porous Al with $p=60,70$ and $80 \%$.

に，白い $\mathrm{Al}$ 部分が減少していることがわかる。また，気孔 率にかかわらず $\mathrm{NaCl}$ の形状が反映された気孔形状が観察さ れ, 圧縮試験片の断面全体でほほ均一な気孔分布となってい ることがわかる。この傾向は圧縮試験片のほぼすべての個所 で観察された。ただし，Fig. 6 に示す気孔率 70\%の圧縮試験 片における高さ方向上部（回転ツールが直接接触した面の近 傍), 中部, 下部（回転ツール接触部から一番離れた部分） のX線CT画像のように，上部では回転ツールの影響で, 若 干，気孔が回転し引き伸ばされたような形状となっている。 しかしながら,この形状が観察されるのは表面から $1 \mathrm{~mm}$ 程 度までであり，他の断面では $\mathrm{NaCl} の$ 形状が反映された気孔 形状が観察された。この傾向は気孔率にかかわらずすべての 試験片で観察された。

Fig. 7 に, 気孔率 $60 \%, 70 \%, 80 \%$ のポーラスアルミニウム 


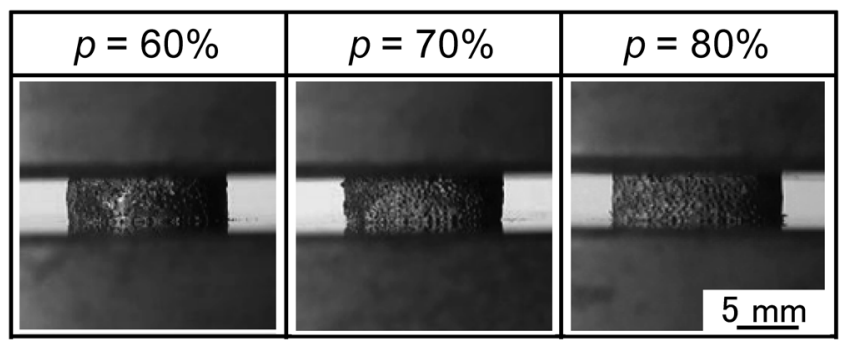

Fig. 8 Deformation images for compressive strain $\varepsilon=40 \%$ during compression tests of fabricated porous Al with $p=60,70$ and $80 \%$.

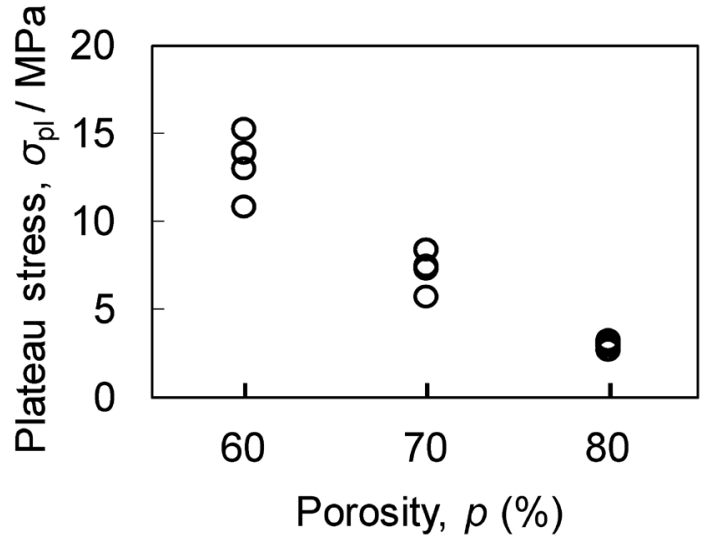

Fig. 9 Relationships between porosity $p$ and plateau stress $\sigma_{\mathrm{pl}}$ for fabricated porous Al.

の圧縮試験から得られた圧縮応力 $\sigma$ と圧縮ひずみ $\varepsilon$ の関係を 示す。圧縮初期に急激に応力が上昇する弾性領域，その後の 応力がほぼ一定で推移するプラトー領域，および圧縮の最

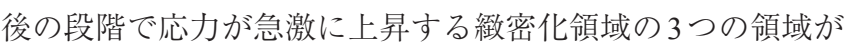
確認され，従来の発泡金属等のポーラス金属の応力ーひずみ 曲線 ${ }^{1)}$ と同様の傾向を示した。Fig. 8 に各気孔率の圧縮ひず み $\varepsilon=40 \%$ における圧縮変形挙動を, 圧縮試験の様子をビデ オ撮影したものから抽出した画像を示す。SDPにおいて焼結 が不足する場合, 崩れるような脆性的な変形挙動を示し, 低 いプラトー応力で応力-ひずみ曲線が不安定に上下に振動す ることが知られている ${ }^{11)}$ 。本研究の場合は, どの気孔率に おいても崩れるような変形挙動は見られず，得られた応 力ーひずみ曲線は，それぞれの気孔率において，SDPの先行 研究 $^{9)}$ １1）の応力-ひずみ曲線とほぼ同様の傾向を示した。 すなわち, 摩擦粉末焼結法により摩擦熱と押込荷重のみで $\mathrm{Al}$ 粉末同士の強固な焼結を伴ったポーラス $\mathrm{Al}$ を作製できる ことがわかった。

Fig.9に, Fig. 7に示した応力ーひずみ曲線から算出したプ ラトー応力值を各気孔率ごとに示す。ここでプラトー応力は JIS-H-7902「ポーラス金属の圧縮試験方法」に基づき，ひず み 20〜30\%における応力の平均值とした ${ }^{18)}$ 。気孔率の増加 とともにプラトー応力が減少しており, 両者に相関があるこ とがわかる。すなわち，気孔率を制御することで，ポーラス $\mathrm{A} 1$ の機械的特性を制御できる可能性が示唆された。しかし ながら, 同じ気孔率であってもばらつきが存在する。この原 因については様々な要因が考えられるが，例えば， $\mathrm{A} 1$ 粉末 の粒径により同じ焼結条件であっても，焼結の度合いが異な

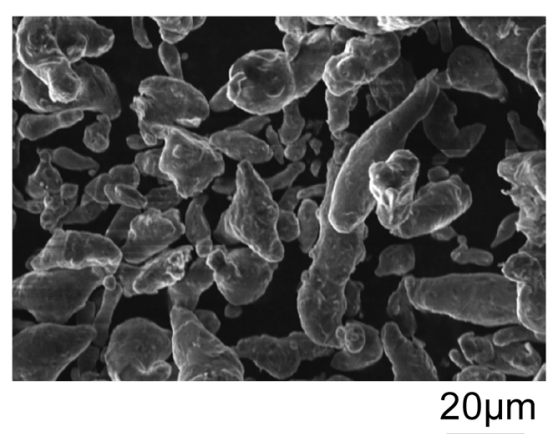

Fig. 10 SEM images of aluminum powder particles used in this study.

り圧縮強度に違いが出ることが知られている ${ }^{11)}$ 。本研究に おいては, 粒径 $20 \mu \mathrm{m}$ 以下の $\mathrm{Al}$ 粉末を用いているが, Fig. 10 に示すように，大きさにばらつきがあるとともに，細長くア スペクト比も大きい。このようなことから, 焼結の度合いに ばらつきが現れた可能性がある。圧縮特性のばらつきを小さ くするために，今後さらなる検討を行うことが必要である。

\section{4. 結言}

本研究では, 摩擦粉末焼結法により気孔率 $60 \%, 70 \%, 80 \%$ のオープンセル型ポーラス $\mathrm{Al}$ を作製した。

得られたポーラス $\mathrm{Al}$ はスペーサーである $\mathrm{NaCl}$ の形状をほ ぼ反映したものとなっていた。ただし，回転ツール接触面の ごく近傍ではツールの回転による影響と考えられる気孔の変 形が見られた。圧縮特性は, 気孔率にかかわらず他の方法で 作製されたポーラス $\mathrm{Al}$ とほぼ同様の傾向を示していた。プ ラトー応力は気孔率の増加とともに低下し, 両者に相関があ ることがわかった。どの気孔率においても，脆性的に崩れる ような変形挙動が見られなかったことから, $\mathrm{Al}$ 粉末同士の 焼結は十分行われていると考えられた。本手法により, 粉末 の焼結が回転ツールと無酸素銅板や粉末との間で発生する摩 擦熱および押达荷重のみで行われることが示された。また, スペーサーに $\mathrm{NaCl}$ を用いることで, スペーサーの除去も常 温の水に浸漬するのみであり, 熱源を一切用いることなく ポーラス $\mathrm{Al}$ が得られた。

以上の結果より, 摩擦粉末焼結法により摩擦熱以外の外部 熱源を用いることなくポーラス $\mathrm{Al}$ の作製が可能であること が示唆された。

\section{謝 辞}

本研究の遂行にあたり, 一般財団法人地域産学官連携もの づくり研究機構の甲本忠史専務理事および久米原宏之常務理 事には，SEM観察に関してご協力を頂きました。本研究の 一部は, 独立行政法人新エネルギー・産業技術総合開発機 構 (NEDO) 平成 21 年度産業技術研究助成事業および公益 財団法人天田財団一般研究開発助成の助成のもと行われまし た。ここに記して，厚く感謝いたします。

\section{参 考 文 献}

1) L. J. Gibson: Annu. Rev. Mater. Sci., 30 (2000), 191-227.

2) H. Nakajima: Prog. Mater. Sci., 52 (2007), 1091-1173.

3) 大串哲朗, 千葉 博, 中嶋英雄：まてりあ, 45 (2006), 228-230.

4) J. Banhart: Prog. Mater. Sci., 46 (2001), 559-632.

5) 小橋 眞：軽金属, 55 (2005), 327-332. 
6) 中嶋英雄監修: マクロおよびナノポーラス金属の開発最前線, シーエムシー出版, (2011).

7）金武直幸, 小橋 眞：軽金属，62（2012），122-134.

8) Y. Y. Zhao and D. X. Sun: Scr. Mater., 44 (2001), 105-110.

9) D. X. Sun and Y. Y. Zhao: Metall. Mater. Trans. B, 34 (2003), 69-74.

10) C. E. Wen, M. Mabuchi, Y. Yamada, K. Shimojima, Y. Chino, H. Hosokawa and T. Asahina: J. Mater. Sci. Lett., 22 (2003), 1407-1409.

11) M. Hakamada, Y. Yamada, T. Nomura, Y. Q. Chen, H. Kusuda and M. Mabuchi: Mater. Trans., 46 (2005), 2624-2628.

12）袴田昌高, 馬㴊 守：軽金属, 62（2012）, 313-321.
13）溶接学会編：摩擦攪拌接合—FSWのすべて一, 産報出版, (2006)

14）摩擦圧接協会編：摩擦接合技術, 日刊工業新聞社, （2006）。

15) Y. Hangai, H. Yoshida and N. Yoshikawa: Metall. Mater. Trans. A, 43 (2012), 802-805.

16) Y. Hangai, H. Yoshida, O. Kuwazuru and N. Yoshikawa: Mater. Trans., 54 (2013), 1057-1059.

17) Y. Hangai, K. Zushida, H. Fujii, R. Ueji, O. Kuwazuru and N. Yoshikawa: Mater. Sci. Eng. A, 585 (2013), 468-474.

18) JIS-H-7902：ポーラス金属の圧縮試験方法, 日本工業標準調査 会, (2008). 